\title{
HUBUNGAN SELF EFFICACY DAN SOLIDARITAS KELOMPOK TERHADAP MINAT PEMUDA BUDDHIS DALAM MENGIKUTI KEGIATAN KEAGAMAAN
}

\author{
DI KECAMATAN GETASAN KABUPATEN SEMARANG \\ Sukodoyo, Situ Asih, Tri Yatno, Agus Subandi \\ Prodi Dharmaduta STAB Negeri Raden Wijaya \\ sukodoyosyailendra@gmail.com
}

\begin{abstract}
ABSTRAK
Penelitian ini bertujuan untuk (1) mengetahui hubungan self-efficacy dengan minat pemuda Buddhis dalam mengikuti kegiatan keagamaan, (2) mengetahui hubungan solidaritas kelompok minat pemuda Buddhis dalam mengikuti kegiatan keagamaan, (3) mengetahui hubungan self-efficacy dan solidaritas kelompok dengan minat pemuda Buddhis dalam mengikuti kegiatan keagamaan di Kecamatan Getasan.

Sampel dalam penelitian ini 116 pemuda Buddhis di Kecamatan Getasan yang berusia 16 sampai dengan 30 tahun. Teknik pengumpulan data menggunakan angket. Ada tiga angket yang digunakan yaitu angket self-efficacy, angket solidaritas kelompok, dan angket minat pemuda Buddhis dalam mengikuti kegiatan keagamaan. Data yang diperoleh diolah dengan menggunakan analisis korelasi berganda melalui program SPSS versi 19.0.

Hasil penelitian menunjukkan bahwa (1) terdapat hubungan antara self-efficacy dengan solidaritas kelompok, yakni sebesar 0,571 dengan tingkat signifikan sebesar 0,000. (2) Terdapat hubungan antara self-efficacy dengan minat pemuda Buddhis dalam mengikuti kegiatan keagamaan, yakni sebesar 0,780 dengan tingkat signifikan 0,000. (3) Terdapat hubungan antara solidaritas kelompok dengan minat pemuda Buddhis dalam mengikuti kegiatan keagamaan, yakni sebesar 0,572 dengan tingkat signifikan sebesar 0,000 . Penelitian ini menunjukkan besarnya hubungan di antara ketiga variabel tersebut yang paling kuat adalah hubungan antara solidaritas kelompok dengan minat pemuda Buddhis, yakni 0,780.
\end{abstract}

Kata kunci: Self-Efficacy, Solidaritas Kelompok, Minat Pemuda Buddhis

\section{ABSTRACT}

This research aimed: (1) to find out the relationship between self-efficacy and Buddhist youth's interest in attending religious activity, (2) to find out the relationship between group solidarity and Buddhist youth's interest in attending religious activity, and (3) to find out the relationship of selfefficacy and group solidarity to Buddhist youth's interest in attending religious activity in Getasan Sub District. The sample of research consisted of 116 Buddhist youth in Getasan Sub District, aged $16-30$ years. Technique of collecting data used was questionnaire. There were three questionnaires used: questionnaires of self-efficacy, group solidarity, and Buddhist youth's interest in attending the activity. The data obtained was processed using multiple correlational analysis using SPSS program version 19.0. The results of research showed as follows. (1) There was relationship between self-efficacy and group solidarity, 0.571 with significance level of $0.000,(2)$ there was a relationship between group solidarity and Buddhist youth's interest in attending religious activity, with score of 0.78 at significance level of 0.000 . (3) There was a relationship of self-efficacy and group solidarity to Buddhist youth's interest in attending religious activity, with score of 0.572 at significance level of 0.000. This research showed the regarding the size of relationship, the strongest relationship among the three variables was the one between group solidarity and Buddhist youth's interest, 0.780 .

Keywords: Self-Efficacy, Group Solidarity, Buddhist Youth's interest.

\section{PENDAHULUAN}

Kegiatan keagamaan menjadi salah satu kegiatan untuk berinteraksi antar masyarakat baik di lingkungan tempat ibadah, dan organisasi keagamaan. Dalam kegiatan tersebut, peran pemuda sangat dibutuhkan bahkan dapat menjadi orang yang memberikan solusi. Di sisi lain kegiatan keagamaan menjadi pijakan dalam menanamkan nilai-nilai agama pada pemuda. Pada dewasa ini para pemuda kurang tertarik untuk melakukan 
kegiatan di tempat ibadah. Hampir sebagian pemuda saat ini yang lebih senang duduk menghabiskan waktu untuk di depan layar komputer atau leptop untuk update status, bermain game online, bermain hand phone, melihat konser musik bersama teman seusia, berkumpul melakukan pesta, jalan-jalan di kota menggunakan sepeda motor. Hasil wawancara pada 5 pemuda (Kabupaten Semarang, 9 Agustus 2014), kurang ketertarikan pemuda pada kegiatan keagamaan dikarenakan kegiatan yang monoton dan rutinitas di tempat ibadah. Menurut 5 pemuda tersebut, bahwa kegiatan berkumpul dengan teman sebaya, jalan-jalan menggunakan motor di sore dan malam hari, dan melihat pertunjukan dangdut lebih menyenangkan. Pemuda yang cenderung tergabung dalam suatu kelompok mempunyai ikatan erat untuk hidup dalam komunitas yang sama.

Kurang atau terbatasnya pemahaman pada nilai-nilai agama menjadi penyebab pemuda yang tergabung dalam kelompokkelompok mempunyai nilai-nilai atau normanorma, sikap dan tradisi sendiri. Fanatisme anggota terhadap kelompok menyebabkan pemuda melakukan perilaku menyimpang. Kegiatan tersebut menyebabkan penyimpangan kelompok lebih berbahaya dibandingkan penyimpangan individu. Sekelompok pemuda di wilayah Sepatan Kabupaten Tangerang terlibat tawuran saat takbiran Idul Adha, Selasa $(15 / 10 / 2013)$ dini hari. Satu orang pemuda bernama Andi tewas dengan tubuh penuh luka bacok. Tawuran terjadi di Kampung Karet Kavling, Desa Karet Selatan, RT 07 RW 03 sekitar pukul 02.30 WIB. Kejadian bermula dari aksi perang mulut antara Rahman alias Tompel warga Kampung Karet, dengan pemuda Kampung Karet Kavling (Kompas, 16 Oktober 2013). Perilaku menyimpang seperti tawuran antara sekelompok pemuda, genk motor, tawuran, seks bebas, sindikat perdagangan narkoba, pengrusakan tempattempat umum, bahkan dapat terlibat dalam kasus terorisme merupakan salah satu contoh penyimpangan yang dilakukan pemuda.

Pemuda merupakan bagian dari usia remaja yang mempunyai peran dan tanggung jawab lebih dari usia perkembangan anakanak. Di sisi lain pemuda mempunyai permasalahan yang dapat bersumber dari dalam diri, keluarga, teman sebaya atau lingkungan sosial. Dalam Peraturan Menteri Pemuda dan Olahraga Nomor 0059 Tahun
2013 tentang Pengembangan Kepemimpinan Pemuda pada pasal 1 ayat 1 dijelaskan pemuda merupakan warga negara Indonesia yang memasuki periode penting pertumbuhan dan perkembangan yang berusia 16 sampai 30 tahun. Rentang usia 16 sampai 30 merupakan pembagian dua rentang masa kehidupan manusia. Pada usia 15 sampai 18 tahun merupakan masa remaja pertengahan, dan 18 sampai 21 tahun merupakan masa remaja akhir (Desmita, 2006: p. 190). Pada hakikatnya periode pertumbuhan dan perkembangan pemuda harus berlangsung dengan baik.

Pemuda harus mampu menyelaraskan antara kondisi yang terjadi dalam diri sendiri dan lingkungan sekitar. Kemampuan menyelaraskan sikap diri dan masyarakat merupakan upaya dalam menyesuaikan diri. Kehidupan pemuda tidak lagi hanya sebatas pada keluarga melainkan pengaruh dari lingkungan sekolah dan pekerjaan, teman dalam kelompok, dan masyarakat memegang peranan penting dalam penyesuaian diri pemuda. Keyakinan pada kemampuan diri dalam melakukan kegiatan keagamaan dapat membantu meningkatkan pemahaman nilainilai agama. Bandura (Ormrod, 2009: p. 21), menyatakan bahwa keyakinan seseorang terhadap kemampuan yang dimiliki untuk mengontrol fungsi diri dan lingkungannya dinamakan self efficacy. Self efficacy mendororong keseluruhan perasaan diri seseorang. Melalui self efficacy, pemuda terdorong minatnya pada kegiatan keagamaan dan secara tidak langsung terkondisi untuk mengendalikan diri, dan tidak merugikan diri dan makhluk lain.

Dalam agama Buddha kegiatan keagamaan yang berlangsung di dalam dan di luar vihara, dan di organisasi kepemudaan Buddhis. Melalui kegiatan organisasi kepemudaan tersebut pemuda diharapkan mampu berinteraksi, dan bekerja sama dalam mengembangkan diri dan melakukan kegiatan yang bermanfaat bagi lingkungan dan sesama manusia. Kegiatan keagamaan yang tepat dan positif mampu menumbuhkan keyakinan dan persatuan di antara pemuda. Keyakinan pada kemampuan diri dan kerja sama antar kelompok merupakan aspek dasar kemajuan organisasi pemuda.

Berdasarkan uraian di atas peneliti mengambil judul "Hubungan Self Efficacy dan Solidaritas Kelompok terhadap Minat Pemuda Buddhis dalam Mengikuti Kegiatan 
Keagamaan". Hal ini dilakukan agar memberikan masukan dan solusi untuk meningkatan minat pemuda dalam mengikuti kegiatan keagamaan.

\section{TUJUAN PENELITIAN}

Penelitian ini bertujuan untuk mengetahui hubungan self efficacy dengan minat pemuda Buddhis dalam mengikuti kegiatan keagamaan, mengetahui hubungan solidaritas kelompok minat pemuda Buddhis dalam mengikuti kegiatan keagamaan, dan mengetahui hubungan self efficacy dan solidaritas kelompok dengan minat pemuda Buddhis dalam mengikuti kegiatan keagamaan

\section{TINJAUAN PUSTAKA} Self Efficacy

Self-efficacy adalah tingkat atau kekuatan keyakinan kemampuan seseorang untuk menyelesaikan tugas dan mencapai tujuan (http://en.wikipedia.org). Bandura menggunakan istilah self efficacy mengacu pada keyakinan (belief) tentang kemampuan seseorang untuk mengorganisasikan dan melaksanakan tindakan untuk pencapaian hasil. Dengan kata lain, self efficacy adalah keyakinan penilaian diri berkenaan dengan kompetensi seseorang untuk sukses dalam tugas-tugasnya. Self efficacy juga berhubungan dengan tingkat kepercayaan diri seseorang dalam menghadapi segala situasi. (Badura, 1997: p. 3) Menurut Bandura, keyakinan self efficacy merupakan faktor kunci sumber tindakan manusia (human egency), "apa yang orang pikirkan, percaya, dan rasakan mempengaruhi bagaimana mereka bertindak". Dengan berdasarkan kepada keyakinan seseorang merasa lebih mantap atau yakin dalam melakukan sebuah tindakan. Perbuatan apapun yang dilakukan jika didasarkan pada keyakinan kemungkinan besar dapat memberikan hasil yang maksimal (Badura, 1997: p. 25).

Suatu contoh dalam kehidupan seharihari bahwa keyakinan efficacy juga mempengaruhi sejumlah stress dan pengalaman kecemasan individu sudah dapat dirasakan sejak dini. Sejak manusia merasakan jenjang pendidikan maka akan mengalami sejumlah kecemasan indvidu. Setiap semester anak dituntut untuk dapat menyelesaikan atau mendapatkan nilai yang bagus. Hal ini dapat mengakibatkan kecemasan individu bahkan stress pada anak. Semakin dewasa manusia juga akan menemukan sebuah pengalaman yang membuat cemas atau dalam bahasa sekarang galau, akan tetapi bila seseorang memiliki keyakinan dalam memutuskan setiap pengalaman yang membuat kebingungan maka hal itu tidak menjadikan sebuah masalah dalam kehidupannya. Dalam riwayat hidup Buddha yang telah ditulis oleh Bhikkhu Kusaladhamma diceritakan pada saat Pangeran Siddhattha bermain bersama-sama temannya, beliau menemukan burung angsa yang terkena anak panah di depannya. Ternyata burung angsa tersebut dipanah oleh sepupunya sendiri yaitu Pangeran Devadatta. Setelah itu terjadi perselisihan antara Pangeran Siddhattha dan Pangeran Devadatta. Perselisihan ini akhirnya diselesaikan di pengadilan. Ini merupakan sikap yang bijak dalam menghadapi sebuah permasalahan, agar tidak terjadi kebingungan (Kusaladhamma, 2009: p. 42)

Secara eksplisit, Bandura sebagaimana dikutip oleh Pajares, menghubungkan self efficacy dengan motivasi dan tindakan, tanpa memperhatikan apakah keyakinan itu benar secara objektif atau tidak. Dengan demikian, perilaku dapat diprediksi melalui self efficacy yang dirasakan (keyakinan seseorang tentang kemampuannya), meskipun perilaku itu terkadang dapat berbeda dari kemampuan aktual karena pentingnya self efficacy yang dirasakan. Keyakinan kemampuan seseorang dapat membantu menentukan hasil yang diharapkan, karena individu memiliki confident dalam mengantisipasi hasil yang sukses. Misalnya, pembelajar yang confident dalam mengantisipasi kemampuan menulis, memiliki nilai yang tinggi dalam tugas kepenulisan dan mengharapkan mutu tugas mereka memperoleh manfaat akademik. Sebaliknya, pembelajar yang ragu-ragu atas kemampuan menulis berpretensi akan memperoleh nilai rendah sebelum mereka mantap mulai menulis.

Perasaan efficacy yang kuat meningkatkan kecakapan seseorang dan kesejahteraan (well-being) dalam cara yang tak terbayangkan. Individu yang confident, memandang tugas-tugas yang sulit sebagai tantangan untuk dikuasai daripada sebagai ancaman untuk dihindari. Mereka memiliki minat yang lebih kuat dan keasyikan yang mendalam pada kegiatan, menyusun tujuan yang menantang mereka, dan memelihara komitmen yang kuat serta mempertinggi dan mendukung usaha-usaha mereka dalam 
menghadapi kegagalan. Mereka lebih cepat memulihkan confident setelah mengalami kegagalan atau kemunduran. Self efficacy yang tinggi membantu membuat perasaan tenang dalam mendekati tugas dan kegiatan yang sulit. Sebaliknya, orang yang meragukan kemampuan dirinya, mereka bisa percaya bahwa sesuatu itu lebih sulit daripada yang sesungguhnya. Dalam hal ini terdapat empat proses besar psikologis di mana self efficacy mempengaruhi fungsi keyakinan manusia yaitu proses kognitif, proses motivasi, proses afektif, dan proses seleksi (Badura, 1994: p. 4).

Self efficacy dalam agama Buddha dapat diartikan sebagai saddha, keyakinan atau kepercayaan. Keyakinan adalah kekayaan yang terbaik yang dapat dimiliki seseorang (S.I,41). Kekayaan yang dimaksud bukan hanya harta benda, tetapi juga sukses dalam kehidupan sosial. Hal ini juga dijelaskan dalam (S.V, 396) bahwa orang yang tak tergoyahkan keyakinannya dan mempunyai kebajikan yang dihargai oleh orang-orang mulia, akan melaju dan mencapai pantai seberang, menuju lenyapnya kekotoran batin. Keyakinan dapat merubah penderitaan menjadi kebahagiaan. Dalam rumusan sebab musabab yang saling bergantungan (S.II, 32) disebutkan bahwa penderitaan menimbulkan keyakinan, keyakinan menimbulkan rasa gembira, rasa gembira menimbulkan rasa terpesona, rasa terpesona menimbulkan ketenangan, ketenangan menimbulkan kebahagiaan, kebahagiaan menimbulkan pemusatan pikiran, pemusatan pikiran menimbulkan pengetahuan dan pandangan akan segala hal sebagai mana adanya, pengetahuan dan pandangan akan segala hal sebagai mana adanya menbebasan menimbulkan kejenuhan, kejenuhan menimbulkan ketiadaan hawa nafsu, ketiadaan hawa nafsu menimbulkan pembebasan, pembebasan menimbulkan pemahaman atau tiada lagi kelahiran kembali. Inilah tujuan akhir atau Nirwana yang dicapai oleh para Arahat (Mukti, 2003: p. 32).

\section{Solidaritas}

Istilah solidaritas dalam kamus ilmiah popular diartikan sebagai kesetiakawanan dan perasaan sepenangguangan. Sementara Paul Jonhson (1986: p. 181) memberikan pengertian bahwa solidaritas sosial menunjuk satu keadaan hubungan antar individu dan/atau kelompok yang didasarkan pada perasaan moral dan kepercayaan yang dianut bersama yang diperkuat oleh pengalaman emosional bersama. Sependapat dengan Johnson, Lawang dalam Soedijati (1995: p. 12) menguraikan bahwa dasar pengertian solidaritas tetap kita pegang yakni kesatuan, persahabatan, saling percaya yang muncul akibat tanggung jawab bersama dan kepentingan bersama diantara para anggotanya.

Konsep solidaritas merupakan konsep sentral Emile Durkheim (1858-1917) dalam mengembangkan teori sosiologi. Durkheim menyatakan bahwa solidaritas merupakan suatu keadaan hubungan antara individu dan atau kelompok yang didasarkan pada perasaan moral dan kepercayaan yang dianut bersama dan diperkuat oleh pengalaman emosional bersama. Solidaritas menekankan pada keadaan hubungan antar individu dan kelompok dan mendasari keterikatan bersama dalam kehidupan dengan didukung nilai-nilai moral dan kepercayaan yang hidup dalam masyarakat. Wujud nyata dari hubungan bersama akan melahirkan pengalaman emosional, sehingga memperkuat hubungan antar mereka. Jadi, solidaritas berarti keadaan dimana individu merasa telah menjadi bagian dari sebuah kelompok. Atas dasar perasaan moral dan kepercayaan ditambah pengalaman emosional bersama sehingga memperkuat hubungan antar mereka.

Ajaran Buddha melandaskan etika bukan hanya atas dasar perasaan welas asih terhadap makhluk lain, namun juga atas dasar kepedulian naluriah terhadap kesejahteraan dan kebahagian dalam jangka waktu panjang. Solidaritas merupakan bagian dari etika dalam kita hidup dalam masyarakat yang berhubungan dengan individu atau kelompok lain yang mempunyai perasaan senasip bahwa kita dilahirkan sebagai manusia di bumi ini. Buddha mengajarkan bahwa keadaan menjadi manusia tidaklah kekal, bahwa semua manusia akan mengalami usia tua, sakit dan mati, mengatasi hal tersebut Buddha mengajarkan Dhamma sebagi obat untuk melepaskan belengggu penderitaan pada makluk hidup (Bodhi, 2009: p. 12)

Kisah Nakulapita sang perumah tangga bersama dengan istrinya menanyakan kepada Sang Buddha mengenai cara supaya Nakulapita dan istrinya bisa bersatu dalam kehidupan yang akan datang, Sang Buddha menjawab jika istri maupun suami berkeinginan untuk tetap bersama dalam kehidupan mendatang, maka mereka harus 
memiliki keyakinan yang sepadan, disiplin moral yang sepadan, kedermawanan yang sepadan, dan kebijaksanaan yang sepadan (Bodhi, 2009: p. 159). Dengan demikian berarti bahwa Solidaritas sangat dibutuhkan dalam kehidupan sekarang maupun yang akan datang.

Perumpamaan mengenai empat manusia yang sebanding dengan pohon dijelaskan dalam Kitab Suci Puggala-Pannati. Sang Buddha menjelaskan ada pohon sendiri yang lemah tetapi dikelilingi yang kuat, ia sendiri kuat tetapi dikelilingi yanng lemah, ia sendiri lemah dan dikelilingi yang lemah, ia sendiri kuat dan dikelilingi yang kuat. Artinya bahwa manusia ada yang mempunyai moral buruk dan jahat dikategorikan sebagai yang lemah dan manusia yang mempunyai moralitas baik dikategorikan sebagai yang kuat, Dalam hal ini tingkat solidaritas antar manusia ada yang lemah dan ada yang kuat (Anggawati, 2012: p. 151).

\section{Minat}

Menurut Slameto, minat adalah rasa lebih suka dan rasa ketertarikan pada suatu hal atau aktivitas, tanpa ada yang menyuruh. Minat pada dasarnya adalah penerimaan akan suatu hubungan antara diri sendiri dengan sesuatu di luar diri. Semakin kuat atau dekat hubungan tersebut, semakin besar minatnya. Menurut Crow \& Crow, mengatakan minat berhubungan dengan gaya gerak yang mendorong seseorang untuk menghadapi atau berurusan dengan orang, benda, kegiatan, pengalaman yang dirangsang oleh kegiatan itu sendiri (Djaali, 2008: p. 121).

Winkel (2004: p. 212), minat diartikan sebagai kecenderungan subyek yang menetap, untuk tertarik pada bidang studi atau pokok bahasan tertentu dan merasa senang mempelajari materi itu. Minat momentan ialah perasaan tertarik pada suatu topik yang sedang dibahas atau dipelajari untuk itu kerap digunakan istilah "perhatian". Perhatian dalam arti "minat momentan", perlu dibedakan dari perhatian dalam arti "konsentrasi", sebagaimana dijelaskan di atas. Antara minat dan berperasaan senang terhadap hubungan timbal balik, sehingga tidak mengherankan kalau seseorang yang berperasaan tidak senang, akan kurang berminat, dan sebaliknya.

Berdasarkan paparan tentang pengertian minat yang disampaikan dari beberapa sumber di atas, maka dapat disimpulkan bahwa minat adalah rasa ketertarikan pada suatu hal atau aktivitas tanpa ada paksaan dan merasa senang untuk mempelajarinya. Rasa ketertarikan tersebut bukan karena paksaan tapi kesadaran yang tinggi karena keinginan yang kuat untuk mencapai tujuannya.

Minat adalah suatu keadaan dimana seseorang mempunyai perhatian terhadap sesuatu dan disertai keinginan untuk mengetahui dan mempelajari maupun membuktikan lebih lanjut W. S Winkel mengatakan bahwa minat adalah kecenderungan yang agak menetap untuk merasa tertarik pada bidang-bidang tertentu dan merasa senang berkecimpung dalam bidang itu (2004: p. 38), sedangkan menurut Witherington (1985: p. 38) minat adalah kesadaran seseorang terhadap suatu objek, seseorang, suatusoal atau situasi tertentu yang mengadung sangkut paut dengan dirinya atau dipandang sebagai sesuatu yang sadar.

Faktor-faktor yang mendasari minat menurut Crow\&Crow yang diterjemahkan oleh Z. Kasijan (1984: p. 4) yaitu faktor dorongan dari dalam, faktor dorongan yang bersifat sosial dan faktor yang berhubungan dengan emosional. Faktor dari dalam dapat berupa kebutuhan yang berhubungan dengan jasmani dan kejiwaan. Timbulnya minat dari diri seseorang juga dapat didorong oleh adanya motivasi sosial yaitu mendapatkan pengakuan dan penghargaan dari lingkungan masyarakat dimana seseorang berada sedangkan faktor emosional memperlihatkan ukuran intensitas seseorang dalam menanam perhatian terhadap suatu kegiatan atau obyek tertentu.

Untuk meningkatkan minat, maka proses pembelajaran dapat dilakukan dalam bentuk kegiatan seseorang bekerja dan mengalami apa yang ada di lingkungan secara berkelompok. Di dalam kelompok tersebut terjadi suatu interaksi antar seseorang yang juga dapat menumbuhkan minat terhadap kegiatan tersebut.

Minat merupakan kesadaran seseorang bahwa suatu obyek, seseorang, suatu soal maupun situasi yang ada hubunganya dengan dirinya. Sang Buddha menjelaskan mengenai minat dalam Kitab Suci Samyutta Nikaya bahwa seseorang yang ingin mencapai pencerahan hendaknya mengembambangkan kewaspadaan akan nafas, yang mendasar atas kesendirian, tanpa nafsu, dan penghentian, yang memuncak pada pembebbasan. Jika ini 
dikembangkan dan diolah akan memberikan manfaat yang besar (Cintiawati, 2011: 3268).

\section{METODE PENELITIAN}

Penelitian ini menggunakan desain penelitian metode deskriptif analitik dan korelasional untuk melukiskan secara sistematis, faktual, secara cermat dan berusaha memberikan gambaran tentang apa saja yang ada hubungannya dengan penelitian kemudian menganalisanya untuk menemukan pemecahan masalah yang dihadapi. Variabel yang dianalisis dalam penelitian ini terdiri dari 3 variabel, yakni: Variabel pertama yang akan diteliti yaitu Self Efficacy, Self Efficacy mengacu pada keyakinan (beliefs) tentang kemampuan seseorang untuk mengorganisasikan dan melaksanakan tindakan untuk pencapaian hasil. Adapun indikator yang digunakan untuk mengukur Self Efficacy terdiri dari: Level, Strength, dan Generality. Variabel yang kedua yang akan dicari apakah ada hubungannya dengan variabel yang lain dalam penelitian ini yaitu Solidaritas Kelompok yang dapat diartikan sebagai perasaan setia kawan yang dimiliki antar sesama anggota kelompok dengan indikator kepedulian, saling memberi dan rela berkorban. Variabel yang ketiga yaitu Minat pemuda Buddhis Indikator yang dinilai ada empat kelompok yaitu perasaaan senang, ketertarikan, perhatian seseorang, dan keterlibatan. Dalam penelitian ini yang menjadi populasinya adalah seluruh generasi muda Buddhis di Kecamatan Getasan, Kabupaten Semarang, Propinsi Jawa Tengah yang berjumlah 116 orang.

Teknik yang dipakai untuk pengambilan data adalah : kepustakaan, kuesioner, dan observasi langsung. Alat untuk pengumpulan data dari responden dikumpulkan dengan memberikan skor untuk alternatif jawaban. Penilaian seluruh variabel akan menggunakan skala Likert yaitu banyaknya alternatif jawaban biasanya ada 5 jawaban, yakni Sangat Setuju (SS), Setuju (S), Netral (N), Tidak Setuju (TS) dan Sangat Tidak Setuju (STS). Apabila item positif, angka terbesar diberikan jawaban Iya, sebaliknya bila item negatif, angka terbesar diberikan pada jawaban Tidak. Untuk itu penulis memberi 5 buah alternatif jawaban dengan skor 1 sampai 5

Cara pengukuran validitas angket kompetensi menggunakan teknik korelasi dengan $\mathrm{r}$ pearson atau koefisien korelasi product momen pearson dengan taraf signifikan 5\% yaitu dengan rumus:

$$
\operatorname{rxy}=\frac{N \sum x y-\left(\sum x\right)\left(\sum y\right)}{\sqrt{\left(N \sum x^{2}-\left(\sum x^{2}\right)\left(N \sum y^{2}-\left(\sum y\right)^{2}\right)\right.}}
$$

Dimana:

rxy $=$ koefisien korelasi antara variable $\mathrm{X}$ dan variable $\mathrm{Y}$.

$\sum x y=$ jumlah perkalian $\mathrm{x}$ dengan $\mathrm{y}$

$\mathrm{x}^{2}=$ kuadrat dari $\mathrm{x}$

$\mathrm{y}^{2}=$ kuadrat dari y (Arikunto, 2009: 70-72)

Lokasi penelitian dilakukan di Kecamatan Getasan, Kabupaten Semarang, Propinsi Jawa tengah. Adapun gambaran umum tentang Kecamatan Getasan adalah sebagai berikut: Kecamatan Getasan terletak di $45 \mathrm{Km}$ dari pusat kota Kabupaten Semarang, lokasi Kecamatan Getasan berbatasan dengan beberapa Kecamatan lain di Kabupaten Semarang, dan tiga Kota serta Kabupaten. Tiga Kota dan Kabupaten yang berbatasan dengan Kecamatan Getasan adalah: Kota Salatiga, Kabupaten Boyolali, dan Kabupaten Magelang, yakni di sebelah Timur berbatasan lagsung dengan Kota Salatiga, Selatan dengan Kota Salatiga dan Kabupaten Boyolali, sebelah Barat berbatasan dengan Kecamatan NgablakKabupaten Magelang, dan sebelah Utara berbatasan dengan Kecamatan BanyubiruKabupaten Semarang. Aktivitas penelitian ini secara dilaksanakan selama Lima (5) bulan, sejak bulan Juli 2014 sampai dengan bulan November 2014.

Instrumen penelitian adalah alat atau fasilitas yang digunakan peneliti dalam mengumpulkan data agar pekerjannya lebih mudah dan hasilnya lebih baik, dalam arti lebih cermat, lengkap dan sistematis sehingga lebih mudah diolah. Variasi jenis instrumen penelitian adalah, angket, ceklis (check-list), atau daftar centang, pedoman wawancara, pedoman pengamatan. (Arikunto, 2006:160)

Penelitian ini menggunakan angket tertutup dalam bentuk skala sikap dari Linkert, berupa pertanyaan atau pernyataan yang jawabannya berbentuk skala deskriptif. Angket tertutup untuk mengungkap data tentang self efficacy, solidaritas kelompok dan minat pemuda Buddhis dalam mengikuti kegiatan keagamaan. Alternatif jawaban menggunakan skala linkert dengan lima alternatif jawaban. 
Dalam penelitian, data mempunyai kedudukan yang paling tinggi, karena data merupakan penggambaran variabel yang diteliti dan berfungsi sebagai alat pembuktian hipotesis. Benar tidaknya data, sangat menentukan bermutu tidaknya hasil penelitian. Sedang benar tidaknya data, tergantung dari baik tidaknya instrumen pengumpulan data. Menurut Umar (2003: p. 87), instrumen yang baik memenuhi lima kriteria yaitu: validitas, reliabilitas, sensitivitas, objektivitas, dan Fisibilitas,. Sebelum digunakan, instrumen dalam penelitian ini akan diuji dengan uji validitas dan uji reliabilitas yang diujicobakan kepada responden populasi sebanyak 30 pemuda tetapi bukan pada sampel. Tempat uji coba di Vihara Vimalakirti Girimarto Wonogiri.

Instrumen yang valid harus dapat mendeteksi dengan tepat apa yang seharusnya diukur. Teknik pengujian SPSS yang digunakan untuk uji validitas dalam penelitian ini adalah menggunakan Corrected Item-Total Correlation dengan bantuan program SPSS version 15.00. Jika $\mathrm{r}$ (korelasi), dengan item tersebut valid. Besarnya $r$ tiap butir pertanyaan dapat dilihat dari SPSS pada kolom Corrected Items Correlation). Kriteria uji validitas secara singkat (rule of tumb) adalah 0,3. Jika Korelasi sudah lebih besar dari 0,3 , pertanyaan yang dibuat dikategorikan valid atau shahih (Setiaji, 2004: 61). Yang dimaksud reliabilitas dalam penelitian ini adalah alat ukur yang dipergunakan secara konstan memberikan hasil yang sama, sehingga dapat dipergunakan sebagai instrumen pengumpulan data. Untuk menguji reliabilitas alat ukur angket dalam penelitian ini menggunakan bantuan software SPSS 15.00. Suatu kuisioner disebut reliable atau handal jika jawaban-jawaban seseorang konsisten (Setiaji, 2004: 60). Untuk uji reliabilitas instrumen, digunakan rumus Alpha dari Cronbach (Umar, 2003: p. 106) sebagai berikut:

$$
\mathrm{R} 11=\left(\frac{k}{k-1}\right)\left(1 \frac{\sum \sigma b^{2}}{\sum \sigma t^{2}}\right)
$$

Keterangan:

$$
\begin{array}{ll}
\mathrm{R} 11 & =\text { reliabilitas instrumen } \\
\mathrm{k} & =\text { Banyaknya butir pertanyaan } \\
\sum \mathrm{o}^{2} b^{2} & =\text { Jumlah varian butir } \\
\mathrm{o}^{\prime} t^{2} & =\text { Varian total }
\end{array}
$$

\section{HASIL PENELITIAN DAN PEMBAHASAN \\ Gambaran Umum Subjek Penelitian}

Gambaran umum subjek penelitian bertujuan untuk memberikan gambaran mengenai subjek yang diteliti, sehingga dapat mudah dipahami oleh pembaca pada umumnya. Gambaran tersebut diperoleh melalui pengumpulan data berdasarkan hasil tes, observasi, dan wawancara yang dianalisis oleh peneliti. Analisis memberikan hasil data yang sebenarnya mengenai kasus yang diteliti yaitu hubungan self-efficacy dan solidaritas kelompok dengan minat pemuda Buddhis dalam mengikuti kegiatan keagamaan pada Pemuda Buddhis di Kecamatan Getasan, Kabupaten Semarang.

Kancah dalam penelitian ini adalah Vihara di Kecamatan Getasan, Kabupaten Semarang. Kecamatan Getasan merupakan wilayah kecamatan di Kabupaten Semarang yang memiliki umat dan Vihara terbanyak. Jumlah umat Buddha di Kecamatan Getasan berdasarkan Badan Pusat Statistik (BPS) Kabupaten Semarang 2012 yaitu 1.929 orang. Data tersebut belum diperbaharui oleh BPS sampai dengan tahun 2014. Kecamatan Getasan merupakan kecamatan yang memiliki umat Buddha terbanyak di Kabupaten Semarang di antara 19 kecamatan yang ada.

Vihara di Kecamatan Getasan berjumlah 15 vihara dan 14 vihara yang bernaung di majelis serta 1 vihara milik pribadi tidak bernaung di majelis manapun. Lima belas vihara tersebut.

Vihara Bakti Suci di Deplongan Wates Getasan merupakan vihara milik pribadi Bapak Joko Singgih Sugiarto salah satu Umat Buddha yang tinggal di Surabaya Jawa Timur. Pada Vihara Bakti Suci tidak memiliki pemuda Buddhis dan tidak terdapat kegiatan keagaman umat Buddha yang terjadwal. Vihara Bakti Suci berada jauh dari pemukiman penduduk dan dijadikan tempat singgah bagi para tamu dan umat lelah dalam perjalanan ke luar kota serta mengadakan kegiatan tentatif.

Kegiatan pemuda di 14 vihara di Kecamatan Getasan terdapat yang berjalan dan tidak. Kegiatan pemuda yang berjalan berada di Vihara Dhammaphala, Gabungan Vihara Wening Sari dan Wening Sakti, dan Vihara Indraloka. Kegiatan pemuda di luar 4 vihara tersebut bergabung pada kegiatan puja bakti umum di vihara. Pemuda di 10 vihara tersebut 
tidak melakukan kegiatan keagamaan dikarenakan belum terdapat sebab yang pasti.

Pemuda Buddhis di Kecamatan Getasan yang berusia 16 sampai dengan 30 tahun sebanyak 10\% berpendidikan Sekolah Dasar (SD), 50\% Sekolah Menengan Pertama (SMP), 35\% Sekolah Menengah Atas (SMA), dan 5\% Perguruan Tinggi. Pada Usia 16 sampai dengan 18 tahun rata-rata siswa SMA dan yang tidak bersekolah sebagian berprofesi sebagai petani, pekerja bangunan, dan karyawan pabrik. Sementaran pemuda yang berusia di antara 18 sampai dengan 30 tahun berprofesi sebagai petani, pekerja bangunan, pekerja pabrik, pekerja di toko, wiraswasta, dan mahasiswa, serta menjadi guru SD. Pemuda Buddhis di Kecamatan Getasan sebanyak 55\% telah menikah dan $45 \%$ belum menikah. Pertimbangan penelitian di Kecamatan Getasan adalah sebagai berikut:

1. Hasil observasi dan wawancara yang peneliti lakukan dengan tokoh umat Buddha dan beberapa Pemuda Buddhis di Kecamatan Getasan terdapat masalah selfefficacy, solidaritas kelompok, dan minat pemuda Buddhis dalam mengikuti kegiatan keagamaan pada Pemuda Buddhis di Kecamatan Getasan, Kabupaten Semarang.

2. Di Getasan belum pernah dilakukan penelitian mengenai hubungan self-efficacy dan solidaritas kelompok dengan minat pemuda Buddhis dalam mengikuti kegiatan keagamaan pada Pemuda Buddhis di Kecamatan Getasan, Kabupaten Semarang.

3. Kegiatan Pemuda Buddhis di 10 Vihara pada Kecamatan Getasan tidak berjalan.

4. Ketua Magabudhi dan Pemuda Buddhis di Kecamatan Getasan mengizinkan dan bersedia untuk dijadikan tempat penelitian.

5. Jumlah subjek dalam suatu suatu vihara dapat terpenuhi, dan populasi pemuda Buddhis di Vihara pada Kecamatan Getasan sebagai berikut berikut:

Tabel 1

Jumlah Pemuda Buddhis di Kecamatan Getasan

\begin{tabular}{llc}
\hline No & \multicolumn{1}{c}{ Nama Vihara } & $\begin{array}{c}\text { Jumlah } \\
\text { Pemuda }\end{array}$ \\
\hline 1 & $\begin{array}{l}\text { Buddhabhumika, } \\
\text { Batur }\end{array}$ & 20 \\
\hline 2 & $\begin{array}{l}\text { Dhammaphala, } \\
\text { Wates, }\end{array}$ & 25 \\
\hline 3 & Wening Sari, Banaran, Wates & 10 \\
\hline 4 & Wening Sakti, Sranti, Wates & 10 \\
\hline 5 & Ananda, Ngelo, Getasan & 5 \\
\hline 6 & $\begin{array}{l}\text { Moggalana, } \\
\text { Sumogawe }\end{array}$ & 5 \\
\hline
\end{tabular}

\begin{tabular}{lll}
\hline 7 & Asajji, Mujo, Sumogawe & 6 \\
\hline 8 & Vidyaloka, Ngroto, Sumogawe & 8 \\
\hline 9 & Indraloka, Dalangan, Sumogawe & 9 \\
\hline 10 & $\begin{array}{l}\text { Dhammasuka, Kenteng, } \\
\text { Sumogawe }\end{array}$ & 5 \\
\hline 11 & $\begin{array}{l}\text { Virya Dhamma, Wates, } \\
\text { Sumogawe }\end{array}$ & 4 \\
\hline 12 & $\begin{array}{l}\text { Vimalakirti, } \\
\text { Sumogawe }\end{array}$ & 4 \\
\hline 13 & Dhammasabbha, Jetak Pendingan, & 5 \\
\hline 14 & $\begin{array}{l}\text { Dharma Pundarika, Pongangan, } \\
\text { Samirono }\end{array}$ & 5 \\
\hline & Total \\
\hline
\end{tabular}

Subjek yang berjumlan 116 pemuda tersebut berasal dari 14 Vihara dari 6 desa di Kecamatan Getasan. Satu Vihara berada di Desa Batur, 3 Vihara berada di Desa Wates, 1 Vihara berada di Desa Getasan, 7 Vihara di Desa Sumogawe, 1 Vihara di Desa Jetak, dan 1 vihara di Desa Samirono. Vihara Buddhabhumika Thekelan berada di ujung selatan Desa Batur dan lereng Gunung Merbabu. Vihara Buddhabhumika merupakan satu Vihara yang terdapat di Desa Batur dan bernanung di Magabudhi. Pemuda Buddhis di Vihara Buddhabhumika Thekelan yang berusia 16 sampai 30 tahun berjumlah 20 orang. Vihara Dhammaphala Deplongan bernaung di Magabudhi, dan Wening Sari Banaran dan Wening Sakti Sranti bernaung di MBI, serta ketiga vihara tersebut berada di Desa Wates. Vihara Buddhabhumika, Dhammaphala, Wening Sari, dan Wening Sakti adalah Vihara yang berada di wilayah Barat Kecamatan Getasan.

Vihara-vihara yang berada di wilayah Getasan Timur di antaranya Vihara Ananda Ngelo, Moggalana, Asajji, Vidyaloka, Indraloka, Dhammasukha, Viriya Dharma, Vimala Kirti, Dhammasabha, dan Dharma Pundarika. Vihara Ananda Ngelo berada di Getasan dan merupakan satu-satunya vihara di Desa Getasan dan bernaung di Magabudhi. Vihara Moggalana Bumiayu, Asajji Mujo, Vidyaloka Ngroto, Indraloka Dalangan, dan Dhammasukha Kenteng bernaung di Magabudhi. Viriya Dharma Wates bernaung di Majelis Persaudaraan Vihara Theravada Indonesia, dan Vihara Vimala Kirti bernaung di MBI.

\section{Analisis Deskriptif Setiap Variabel Penelitian}

analisis deskriftif dalam penelitian pene;itian ini meliputi uji validitas, uji reliabilitas dan analisis korelasional. Analisis 
deskriptif dilakukan dengan tujuan untuk memperoleh gambaran mengenai suatu variabel, gambaran tersebut memuat tentang nilai maksimum, nilai minimum, means dan standar deviasi.

\section{Self-efficacy}

Data kuisioner untuk mengukur variabel self-efficacy di deskripsikan dengan bantuan program Statistical Package for Social Sciences (SPSS) for Windows versi 19.00.

Self-efficacy dengan jumlah responden (N) adalah 30, dengan aspek yang diukur meliputi: level, strenght dan generality skor bergerak dari nilai 1,00 sampai dengan 5,00. Adapun rata-rata jawaban responden adalah 20.93 dan standar deviasi atau simpangan bakunya adalah sebesar 4,290. Instrumen yang digunakan untuk mengukur self-efficacy terdiri dari 7 item soal yang masing-masing terdiri dari jawaban yang sudah dikategorikan dari 5 (Sangat setuju), 4 (setuju), 3 (Netral), 2 (tidak setuju) dan 1 (sangat tidak setuju).Selanjutnya melalui histogram berikut ini dapat diketahui bahwa sebagian besar responden memiliki selfefficacy yang cukup tinggi.

\section{Solidaritas Kelompok}

Data kuisioner untuk mengukur variabel Solidaritas kelompok di deskripsikan dengan bantuan program SPSS for Windows versi 19.00 dengan hasil sebagai berikut: variabel solidaritas kelompok dengan jumlah responden (N) adalah 30, dengan aspek yang diukur meliputi: rasa kepedulian, saling memberi dan rela berkorban, skor bergerak dari nilai 1,00 sampai dengan 5,00. Adapun rata-rata jawaban responden adalah 19,63 dan standar deviasi atau simpangan bakunya adalah sebesar 5,410. Instrumen yang digunakan untuk mengukur Solidaritas kelompok terdiri dari 7 item soal yang masing-masing terdiri dari jawaban yang sudah dikategorikan dari 5 (Sangat setuju), 4 (setuju), 3 (Netral), 2 (tidak setuju) dan 1 (sangat tidak setuju). Selanjutnya melalui histogram berikut ini dapat diketahui bahwa sebagian besar responden memiliki solidaritas kelompok yang cukup tinggi.

\section{Minat Pemuda Buddhis}

Data kuisioner untuk mengukur variabel Minat pemuda Buddhis dalam mengikuti kegiatan keagamaan Buddha di deskripsikan dengan bantuan program SPSS for Windows versi 19.00 dengan hasil sebagai berikut:bahwa variabel minat pemuda Buddhis dalam mengikuti kegiatan keagamaan Buddha dengan jumlah responden $(\mathrm{N})$ adalah 30 , dengan aspek yang diukur meliputi: perasaaan senang, ketertarikan, perhatian seseorang, dan keterlibatan. Skor bergerak dari nilai 1,00 sampai dengan 5,00. Adapun rata-rata jawaban responden adalah 20,50 dan standar deviasi atau simpangan bakunya adalah sebesar 4,876. Instrumen yang digunakan untuk mengukur Solidaritas kelompok terdiri dari 7 item soal yang masing-masing terdiri dari jawaban yang sudah dikategorikan dari 5 (Sangat setuju), 4 (setuju), 3 (Netral), 2 (tidak setuju) dan 1 (sangat tidak setuju). Selanjutnya melalui histogram berikut ini dapat diketahui bahwa sebagian besar responden memiliki minat untuk mengikuti kegiatan keagamaan Buddha yang dapat dikatakan kurang.

\section{Uji Validitas dan Reliabilitas}

Hasil uji validitas dan reliabilitas awal dapat diketahui bahwa:

a. Dari 7 soal untuk mengukur self-efficacy, 5 soal valid dan reliabel sedangkan 2 soal lainya tidak valid, sehingga item soal dibuang.

b. Dari 7 item soal untuk mengukur solidaritas kelompok, 7 soal memiliki tingkat validitas yang tinggi dan juga memiliki reliabilitas yang baik, sehingga ke 7 soal layak untuk diujikan kepada responden, tanpa ada yang dibuang.

c. Dari 7 item soal untuk mengetahui minat pemuda Buddhis dalam mengikuti kegiatan keagamaan hanya 5 item soal yang memiliki validitas dan reliabilitas yang baik, sehingga 2 soal yang tidak memenuhi reliabilitas dan validitas dibuang.

\section{ANALISIS DATA DAN PEMBAHASAN Analisis Korelasi}

Instrumen yang telah diuji validitas dan reliabilitas, langkah selanjutnya diujikan kepada responden yang berjumlah 116 orang, untuk kemudian diperoleh data untuk diuji besarnya hubungan antar variabel. Untuk mengetahui besarnya hubungan maka data dianalisis dengan Correlation dengan menggunakan SPSS For Windows versi 19.00.

Adapun data yang telah dikumpulkan dari responden yang berjumlah 116 responden, selanjutnya dilakukan teknik pengkodean, yakni merubah pilihan jawaban dari responden yang awalya berupa huruf sebagai simbol 
sangat setuju, setuju, netral, tidak setuju dan sangat tidak setuju pada pernyataan yang telah diuji validitas dan reliabilitasnya, diperoleh hasil sebagai berikut:

Tabel 2

Correlations

\begin{tabular}{lllll}
\hline & & & $\begin{array}{l}\text { Solidar } \\
\text { itas }\end{array}$ & Minat \\
\hline Self & Pearson & $\mathbf{1}$ & $\mathbf{, 5 7 1}$ & $\mathbf{, 5 7 2}$ \\
& Correlation & & $(* *)$ & $(* *)$ \\
& Sig. (2-tailed) & &, 000 &, 000 \\
& N & 116 & 116 & 116 \\
\hline Solida & Pearson & $\mathbf{, 5 7 1}$ & $\mathbf{1}$ & $\mathbf{, 7 8 0}$ \\
ritas & Correlation & $\mathbf{( * * )}$ & & $\mathbf{( * * )}$ \\
& Sig. (2-tailed) &, 000 & &, 000 \\
& N & 116 & 116 & 116 \\
\hline Minat & Pearson & $\mathbf{5 7 2}$ & $\mathbf{, 7 8 0}$ & $\mathbf{1}$ \\
& Correlation & $\mathbf{( * * )}$ & $\mathbf{( * * )}$ & \\
& Sig. (2-tailed) &, 000 &, 000 & \\
& N & 116 & 116 & 116 \\
\hline
\end{tabular}

** Correlation is significant at the 0.01 level (2-tailed).

Berdasarkan tabel 2 dapat dijelaskan bahwa pada populasi 116 responden selfefficacy memiliki hubungan dengan minat pemuda Buddhis sebesar 0,572 dan signifikan pada tingkat signifikansi 0,000 , sedangkan hubungan solidaritas dengan dengan minat pemuda Buddhis sebesar 0,780 dan signifikan pada tingkat signifikansi 0,000 .

Hubungan self-efficacy dengan minat pemuda Buddhis, dan hubungan olidaritas mkelompok dengan minat pemuda Buddhis terlihat hasil positif dan signifikan.

Berdasaran hasil pengolahan data tersebut yakni dengan melihat besarnya hubungan antara self-efficacy dengan minat pemuda Buddhis dalam mengikuti kegiatan keagamaan sebesar 0,572. Hasil tersebut sesuai dengan analisis Pajares, F. dan Miller, M.D, (1994: 193), bahwa perasaan efficacy yang kuat meningkatkan kecakapan seseorang dan kesejahteraan (well-being) dalam cara yang tak terbayangkan. Individu yang confident, memandang tugas-tugas yang sulit sebagai tantangan untuk dikuasai daripada sebagai ancaman untuk dihindari. Pemuda memiliki minat yang lebih kuat dan keasyikan yang mendalam pada kegiatan, menyusun tujuan yang menantang, dan memelihara komitmen yang kuat serta mempertinggi dan mendukung usaha-usaha mereka dalam menghadapi kegagalan. Pemuda lebih cepat memulihkan confident setelah mengalami kegagalan atau kemunduran. Self-efficacy yang tinggi membantu membuat perasaan tenang dalam mendekati tugas dan kegiatan yang sulit.
Sebaliknya, orang yang meragukan kemampuan dirinya, orang tersebut bisa percaya bahwa sesuatu itu lebih sulit daripada yang sesungguhnya.

Besar hubungan antara self-efficacy dengan solidaritas kelompok yang mencapai 0,571 dengan tingkat signifikansi 0,000 dapat dijelaskan bahwa hasil penelitian ini sesuai dengan empat sumber utama yang mempengaruhi self-efficacy, satu diantaranya adalah bujukan sosial (Bandura, Error! Hyperlink reference not valid., diakses 8/9/2014). Bujukan sosial merupakan suatu sikap yang muncul pada diri individu karena adanya pengaruh dari orang lain dalam suatu kelompok, pengaruh ini bisa berupa pesanpesan verbal maupun pesan non verbal. Seorang individu dapat terpengaruh oleh anggota kelompok yang lain karena adanya solidaritas di antara anggota kelompok, sehingga jelas bahwa self-efficacy memiliki hubungan yang kuat terhadap solidaritas kelompok.

Hasil penelitian ini juga menjelaskan bahwa berdasarkan pengolahan data dengan SPSS For Windows versi 19.00 dapat diketahui bahwa, antara solidaritas kelompok dengan minat pemuda Buddhis dalam mengikuti kegiatan keagamaan memiliki hubungan yang sangat besar, yakni 0,780 dengan tingkat signifikansi 0,000. Kekompakan dan solidaritas mengacu pada kekuatan, baik positif maupun negatif, yaitu tingkat rasa suka satu sama lain antara anggota kelompok, motivasi, dan interaksi tiap anggota kelompok (Festinger dalam Sears, 1994: 109).

Motivasi merupakan bentuk minat pemuda dalam mengikuti kegiatan keagamaan, di mana dengan adanya solidaritas sesama anggota kelompok maka individu mengalami keterdekatan, kehangatan, dan interaksi komunikasi dengan anggota lain. Keterikatan dengan kelompok teman sebaya mendorong bagi tumbuhnya solidaritas dan kekompakan. Dijelaskan Suprapto (2003: 4) bahwa adanya sikap pertemanan yang saling menghargai, menghormati, dan mengerti akan keragaman identitas dalam alur hubungan timbal balik yang harmonis antar individu akan memunculkan kesetiakawanan dan solidaritas. Rasa peduli terhadap masalah yang dihadapi teman sebayapun semakin tinggi, hal ini disebabkan adanya hubungan timbal balik saling memberi dan saling membantu sehingga 
kesusahan seseorang menjadi kesusahan bersama.

Selain pengolahan data dengan SPSS For Windows versi 19.00 tersebut dapat dijelaskan tentang hasil observasi dan wawancara kepada para pemuda Buddhis di Kecamatan Getasan, Kabupaten Semarang yang menunjukkan bahwa: hal utama apa yang membangkitkan minat para pemuda Buddhis dalam mengikuti kegiatan keagamaan adalah kegiatan keakraban, outbound, latihan dasar kepemimpinan, pelatihan keterampilan dan kreativitas, vocal group dan kesenian, dan Dhamma Camp pada Pemuda Theravada Indonesia, Sekretaris Bersama Pemuda Buddhayana, kegiatan perayaan hari-hari besar agama Buddha, kegiatan anjangsana, ataupun kegiatan yang lain. Kegiatan-kegiatan tersebut diyakini oleh subjek dapat terwujud dengan adanya perasaan saling memiliki dan perasamaan visi dan misi untuk perkembangan Buddha Dharma. Perasaan yang tumbuh dalam bentuk minat para pemuda dalam mengikuti kegiatan keagamaan adalah bentuk dari solidaritas kelompok.

\section{KESIMPULAN DAN SARAN}

\section{Kesimpulan}

Berdasarkan pada latar belakang dan landasan teori serta pembahasan hasil penelitian dapat dijelaskan bahwa ada hubungan yang kuat antara self-efficacy dengan solidaritas kelompok dan minat pemuda Buddhis dalam mengikuti kegiatan keagamaan. Adapun besarnya hubungan antar variabel tersebut adalah sebagai berikut:

1. Ada hubungan antara self-efficacy dengan solidaritas kelompok, yakni sebesar 0,571 dengan tingkat signifikansi sebesar 0,000 .

2. Ada hubungan antara self-efficacy dengan minat pemuda Buddhis dalam mengikuti kegiatan keagamaan, yakni sebesar 0,780 dengan tingkat signifikansi 0,000 .

3. Ada hubungan antara solidaritas kelompok dengan minat pemuda Buddhis dalam mengikuti kegiatan keagamaan, yakni sebesar 0,572 dengan tingkat signifikansi sebesar 0,000. Berdasarkan kerangka pikir dan hasil penelitian dapat digambarkan sebagai berikut:

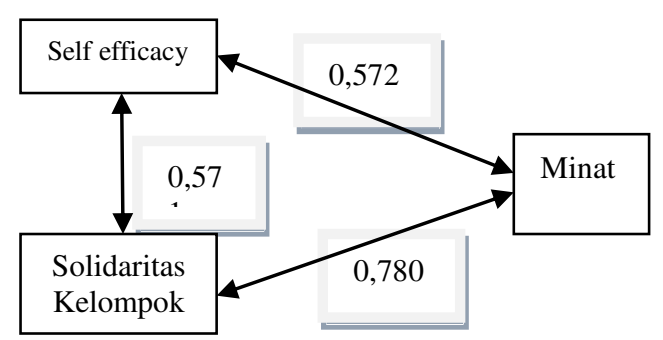

Gambar 1

Hasil Penelitian

Berdasarkan hasil Penellitian seperti terlihat pada gambar 1, dapat dijelaskan bahwa antara variabel self-efficacy, solidaritas kelompok, dan minat pemuda Buddhis memiliki hubungan, adapun besarnya hubungan di antara ketiga variabel tersebut yang paling kuat adalah hubungan antara solidaritas kelompok dengan minat pemuda Buddhis, yakni 0,780.

\section{Saran}

Berdasarkan hasil penelitian yang menyatakan bahwa terdapat hubungan yang kuat antara self-efficacy, solidaritas kelompok, dan minat pemuda Buddhis dalam mengikuti kegiatan keagamaan Buddha, maka peneliti memberikan saran sebagai berikut:

1. Pemuda Buddhis hendaknya memiliki minat yang besar terhadap kegiatan keagamaan, dan perlu meningkatkan selfefficacy dalam diri individu pemuda Buddhis.

2. Pemuda Buddhis hendaknya meningkatkan self-efficacy dan solidaritas sesama anggota kelompok untuk menumbuhkan minat pemuda Buddhis dalam mengikuti kegiatan keagamaan Buddha.

3. Pengurus Vihara, Pemuka Agama, dan orang tua hendaknya memberikan dukungan pada kegiatan keagamaan yang dilakukan oleh Pemuda Buddhis.

4. Organisasi Pemuda Buddhis diharapkan mengadakan kegiatan keagamaan yang mengutamakan pengembangan kreativitas dan disesuaikan dengan tahap perkembangan pemuda.

\section{Daftar Pustaka}

Anggawati Lany, Cintiawati Wena. 2000. Panduan Tipitaka. Kitab Suci Agama Buddha. Klaten: Vihara Bodhivamsa 
Anggawati Lany, Cintiawati Wena. 2012. Puggala-Pannatti, Kitab Suci Agama Buddha, Kitab ke-4 dari Abhidhamma Pitaka. Klaten: Vihara Bodhivamsa.

Arikunto, Suharsimi. 2004. Prosedur Penelitian: Suatu pendekatan Praktek. Bandung: Rineka Cipta.

Albert Bandura. 1997. Self-efficacy: The Exercise of Control (New York. W.H. Freeman)

Albert Bandura.1986. Social Foundations of Thought and Action: A Social Cognitive Theory (Englewood Cliffs, NJ: Prentice Hall)

Badudu dan Zein. 1994. Kamus Umum Bahasa Indonesia 2. Jakarta; Pustaka Sinar Harapan.

Bandura, A .1997. Self-efficacy. In V. S. Ramachaudran (Ed.), Encyclopedia of human behavior (Vol. 4, pp. 71-81). New York: Academic Press. (Reprinted in H. Friedman [Ed.], Encyclopedia of mental health. San Diego: Academic Press, 1998)

(http://www.uky.edu/ eushe2/Bandura/

Bandura1994EHB.pdf diakses tanggal 30 September 2014)

Bodhi. 2009. Tipitaka Tematik, Sabda Buddha dalam Kitab Suci Pali. Ehipassiko Collection

Cintiawati Wena, Widyawati Endang, Anggawati Lany. 2011. Samyutta Nikaya 10, Kitab Suci Agama Buddha. Klaten: Vihara Bodhivamsa.

Cintiawati Wena, Widyawati Endang, Anggawati Lany. 2010. Samyutta Nikaya 6, Kitab Suci Agama Buddha. Klaten: Vihara Bodhivamsa.

D.H. Schunk dan A.R. Hanson.1985. "Peer Model: Influence on children's selfefficacy and achievement. Journal of Educational Psychology.

D.H. Schunk. 1981. Modeling and Attributional Effects on Children's Achievement: A Self-efficacy Analysis, Journal of Educational Psychology.

Damsar. 1997. Sosiologi Ekonomi, Cetakan Pertama. Jakarta: Penerbit PT Raja Grafindo Persada.

Desmita. 2006. Psikologi Perkembangan. Bandung: Remaja Rosdakarya.

Doyle Paul Johnson, 1994, Teori Sosiologi Klasik dan Modern, Terjemahan Robert M. Z. Lawang, Penerbit PT. Gramadia Pustaka Utama, Jakarta.
Gerungan, W.A, 1996. Psikologi Sosial, Bandung: Eresco.

Djaali. 2008. Psikologi Pendidikan. Jakarta: Bumi Aksara

Hurlock, Elizabeth 1995. Psikologi Perkembangan. Jakarta: Erlangga

Paul, Johnson. 1986. Teori Sosiologi Klasik dan Modern, terj. Robert Lawang, Jakarta: Gramedia

Kantor Media Tempo dirusak sekelompok Pemuda. Error! Hyperlink reference not valid.. Diakses, 9 Agustus 2014.

Kasijan. Z, 1984. Psikologi Pendidikan. Surabaya: PT. Bima Aksara.

Kusaladhamma Bhikkhu. 2009. Kronologi Hidup Buddha. Jakarta: Ehipassiko Foundation.

Lawang MZ. 2004. Teori Sosiologi Klasik dan Modern. Jakarta. Gramedia: Pustaka Utama.

Muhibbin Syah. 2011. Psikologi Pendidikan dengan Pendekatan Baru. Jakarta: Remaja Rosdakarya.

Mukti Krishnanda Wijaya. 2003. Wacana Buddha Dharma. Jakarta: Yayasan Dharma Pembangunan

Ormrod, J.E. 2009. Psikologi Pendidikan: Membantu Siswa Tumbuh dan Berkembang, jilid 2. Terjemanah Amatya Kumara. Jakarta: Erlangga.

Pajares, F. dan Miller, M.D. 1994. The Role of Self-efficacy Beliefs and Self-Concept Beliefs in Mathematical ProblemSolving: A Path Analysis. Journal of Educational Psychology

Pajares, G. Nichols, dan A.T.Miller. 1984. Developmentand its discontents: The differentiation of the concept of ability" dalam J.G. Nicholls (ed.), Advances in motivation and achievement, Vol. 3, Greenwich: CT: JAI Press.

Peraturan Menteri Pemuda dan Olahraga Republik Indonesia Nomor 0059 Tahun 2013 Tentang Pengembangan Kepemimpinan Pemuda.

Poerwadarminta. W. J. S. 2007. Kamus Umum Bahasa Indonesia Edisi Ketiga. Jakarta: Balai Pustaka.

Salim, P. dan Salim, Y. 1991. Kamus Bahasa Indonesia Kontemporer. Jakarta: Modern English Press.

Sears David O; Jonathan L Freedman; dan 1. Anne peplau. 1991. Psikologi Sosial. Alih bahasa Michael Adryanto dan 
Savitri Soekrisno. Ed. 5, Jilid 1. Jakarta: Erlangga.

Sears, D.O. Freedman, J.L, Peplau, L.A. 1994. Psikologi Sosial I. Alih Bahasa. Adriyanto dan Soekrisno. Jakarta : Erlangga Self-efficacy Analysis, Journal of Educational Psychology

Setiaji. 2004. Panduan Riset Dengan Pendekatan Kuantitatif. Surakarta: PPS Universitas Muhamadiyah

Self-efficacy (http://en.wikipedia.)org/wiki/Selfefficacy, diakses 8 September 2014)

Slameto. 2003. Belajar dan Faktor-Faktor yang Mempengaruhinya. Jakarta: PT Rineka Cipta.

Soedijati, Elisabeth, Koes. 1995. Solidaritas dan Masalah Sosial Kelompok Waria. Bandung: UPPM STIE Bandung.

Soekanto, S. 1990. Sosiologi Suatu Pengantar. Jakarta : Rajawali Press.

Soerjono Soekanto. 1985. Perspektif Teoritis Studi Hukum Dalam Masyarakat. Jakarta: Rajawali Press.

Sudarsono. 1991. Kamus Filsafat dan Psikologi. Jakarta : Rineka Cipta.

Suhartini Dewi . 2001. Minat Siswa Terhadap Topik-topik Mata Pelajaran Sejarah dan Beberapa Faktor Yang Melatar Belakanginya. Disertasi. PPS Universitas Pendidikan Indonesia.

Sumadi Suryabrata. 2005. Pengembangan Alat Ukur Psikologis. Yogyakarta: Andi.

Suprapto. 2003. Karakteristik, Penerapan, dan Pengembangan Agroindustri Hasil Pertanian di Indonesia. Jakarta: Universitas Mercu Buana.

Umar, Husein. 2003. Metodologi Penelitian Untuk Skripsi dan Tesis Bisnis.Jakarta : PT. Gramedia Pustaka

V. Keysers dan J. Barling, Determinats of childrent's self-efficacy from a crosscultural perspective. International Journal of Psychology

Walgito, Bimo. 2003. Psikologi Sosial. Yogyakarta: Andi Yogyakarta

Willy S. 1989. Kitab Suci Dhammapada. Maha Vihara Mojopahit Trowulan Mojokerto

Winkel. 2004. Psikologi Belajar. Jakarta : PT. Gramedia Pustaka Utama

Witherington. 1985. Psikologi Pendidikan. Jakarta: Aksara Baru

Y.A. Wang dan R.S. Richard "Development of memory monitoring and self-efficacyin children" dalam Psychological Reports (No. 60, 1987), hlm. 647-658. 


\section{PEDOMAN PENULISAN ARTIKEL UNTUK JURNAL PENDIDIKAN, SAINS SOSIAL DAN AGAMA}

1. Jurnal Pendidikan, Sains Sosial dan Agama memuat hasil hasil penelitian, maupun kajian yang terkait dengan hasil penelitian pengembangan, maupun penelitian penerapan dalam bidang pendidikan, ilmu sosial dan agama. Artikel yang dikirim ke redaksi belum pernah dipublikasikan dan dikemas kembali sesuai dengan format artikel jurnal.

2. Panjang naskah +20 halaman A4, minimal 7000 kata, satu setengah spasi, Times New Roman, font 11 , dan ditulis menggunakan Bahasa Indonesia yang baik dan benar.

3. Artikel ditulis dengan ketentuan sebagai berikut:

a. Judul maksimal 15 kata, dengan font 14. Peringkat judul disusun sebagai berikut:

PERINGKAT SATU (HURUF BESAR SEMUA, TEBAL, font 14, di tengah-tengah halaman) PERINGKAT DUA (HURUF BESAR, TEBAL, di tengah-tengah)

PERINGKAT TIGA (HURUF BESAR, TEBAL, di tengah-tengah)

b. Nama penulis tanpa gelar ditulis di bawah judul: untuk Tim semua nama penulis dicantumkan

c. Nama instansi ditulis di bawah nama: email ditulis di bawah nama instansi

d. Abstrak ditulis dalam bahasa Indonesia maupun Bahasa Inggris, satu spasi, 100-200 kata, satu paragraf dan font 11 .

e. Kata kunci merupakan inti permasalahan, bisa satu kata atau lebih, ditulis miring di bawah abstrak dengan jarak satu spasi.

f. Batang tubuh artikel: artikel kajian terdiri dari Pendahuluan (permasalahan, kerangka pikir, dan atau kerangka analisis), sub-sub judul pembahasan, dan kesimpulan; sedangkan artikel hasil penelitian terdiri dari pendahuluan ( latar belakang permasalahan, dan landasan teori), metode penelitian, hasil penelitian dan pembahasan, kesimpulan, dan saran.

4. Kutipan harus disebutkan nama pengarang, tahun ,dan p. nomor halaman. Contoh: (Triyatno, 2014, p.89). kutipan langsung (persis aslinya) lebih dari tiga baris ditulis satu spasi, rata kiri dan menjorok ke kanan 7 ketukan.

5. Artikel rangkap dua disertai soft copynya dikirim ke sekretariat redaksi Jurnal Agama Buddha dan Ilmu Pengetahuan, penulis dari luar kota bisa mengirimkan artikel secara elektronik melalui email: p3mradenwijaya@yahoo.co.id

6. Daftar pustaka disusun dengan tata cara seperti beberapa contoh berikut dan diurutkan secara alfabetis nama pengarang. Tata cara yang tidak ada pada contoh merujuk pada APA style. 


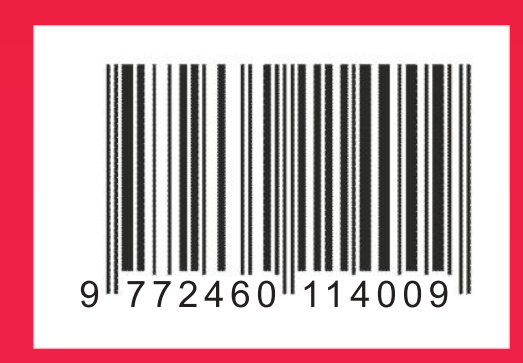

